\title{
Survey on the Incidence of Chilo partellus (Swinhoe) in Krishna and Guntur Districts of Andhra Pradesh, India
}

\author{
K. Anil Kumar ${ }^{1 *}$, T. Madhumathi ${ }^{1}$, D.V. Sai Ram Kumar ${ }^{1}$, \\ N. Raj Kumar ${ }^{2}$ and Sk. Nafeez Umar ${ }^{3}$ \\ ${ }^{1}$ (Entomology), Agricultural College, Bapatla, India \\ ${ }^{2}$ (Plant Pathology) ARS, Amudalavalasa, India \\ ${ }^{3}$ (Statistics), Agricultural College, Bapatla, India \\ *Corresponding author
}

\begin{abstract}
A B S T R A C T
Keywords

Chilo partellus,

Survey, Incidence,

Guntur, Krishna

Article Info

Accepted:

24 May 2019

Available Online:

10 June 2019

A roving survey in maize growing mandals in Krishna and Guntur districts during kharif 2017-18, kharif 2018-19 to record the incidence and damage per cent of Chilo partellus (swinhoe) in the farmer fields. In Krishna district, the maximum leaf infestation was observed in Musunuru mandal in 2017-18 (20.33\%) and 2018-19 (24.99) and lowest infestation is recorded in Veerullapadu mandal in 2017-18 (8.59\%) and 2018-19 (11.92). In Guntur district, the maximum leaf infestation was observed in Pedanandipadu mandal in 2017-18 (22.68\%) and 2018-19 (24.11) and lowest infestation is recorded in Narsaraopet mandal and in 2017-18 (9.84\%) and 2018-19 (14.91). However, overall mean infestation was high in Guntur district in kharif 2017-18 (16.68\%), 2018-19 (21.56\%) than in Krishna district in kharif 2017-18 (13.03\%) and 2018-19 (17.76\%).The per cent dead hearts, stem tunneling, no of larvae, no of pupae and exit holes also followed the same trend.
\end{abstract}

\section{Introduction}

Maize is an important cereal crop which plays a prominent role in the Indian economy and used as food, feed and industrial crop globally. At present, out of the total maize produced, 55 per cent is used for human food, about 14 per cent for livestock, 18 per cent for poultry feed, 12 per cent for starch and one per cent as seed purpose (Singh et al., 2011).Being versatile crop, maize can be grown in all seasons viz; kharif (monsoon), post monsoon, Rabi (winter) and spring. The predominant maize growing states that contributes more than $80 \%$ of the total maize production are Andhra Pradesh (20.9\%), Karnataka (16.5\%), Rajasthan (9.9\%), Maharashtra (9.2\%), Bihar (8.9\%), Uttar Pradesh (6.4\%), Madhya Pradesh (5.2\%), Himachal Pradesh (4.4\%). Hence, the maize has emerged as important crop in the peninsular India like the state of Andhra Pradesh which ranks $5^{\text {th }}$ in area $(0.79 \mathrm{~m} \mathrm{ha})$ has recorded the highest production $(4.14 \mathrm{~m} \mathrm{t})$ and productivity $\left(5.26 \mathrm{t} \mathrm{ha}^{-1}\right)$ in the country although the productivity in some of the 
districts of Andhra Pradesh is more or equal to the USA $\left(10.57 \mathrm{t} \mathrm{ha}^{-1}\right)$. C. partellus, is the key pest playing havoc role all over the world and reported to cause losses ranging between 5.14 to 91.22 per cent (Singh and Sajjan, 1982). The infestation occurs when the seedlings are two weeks old up to cob formation stage.

\section{Identification}

Eggs

Eggs are white colored, scale like eggs in overlapping rows laid usually on underside of the leaves.

\section{Larvae}

The young larvae are small, spotted and yellowish with brown head, while fully grown larvae are 20 to $25 \mathrm{~mm}$ long with colored stripes along the back of the body.

\section{Adult}

The adult is straw-colored or yellowish brown colored and grown up to $15 \mathrm{~mm}$ long.

\section{Materials and Methods}

The survey was conducted in two consecutive years during kharif, 2017-18 and 2018-19, in maize growing fields of Krishna and Guntur districts of Andhra Pradesh, at two different stages of the crop (vegetative and harvesting stages). The survey was done to ascertain the infestation of $C$. partellus in the surveying districts. In each mandal, of a district the maize growing villages were selected and in each village four fields were selected at random. In each field 20 plants from four corners leaving the boarder rows and another 20 plants at centre were selected to record the infestation of $C$. partellus. Simultaneously the natural enemies in maize ecosystem were also recorded and the farmers were also interviewed to record the history of the crop.

The per cent plant infestation and per cent dead hearts were calculated by using the formula:
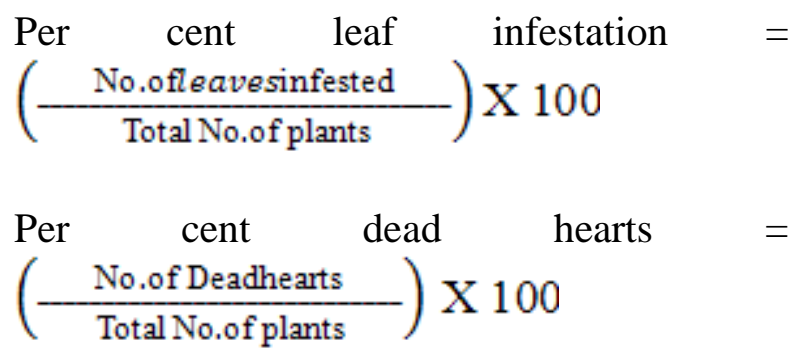

At the time of harvest the stems were split opened to count the number of larvae, pupae, exit holes and stem tunneling of the larva was measured and the percentage tunneling was calculated using the formula:

Length of tunneling $(\mathrm{cm})$

Per cent Tunneling $=$------------------- $\times 100$ Length of stem up to cob height $(\mathrm{cm})$

\section{Results and Discussion}

During kharif, the survey was made in four randomly selected farmer fields in four maize growing villages during 2017-18 and 2018-19 (Table 1). The survey results showed that in Guntur district the range of deadhearts percentage is from 4.16 to 21.87 per cent, with leaf infestation of 9.84 to 24.11 per cent and tunnel length ranging from 1.6 to 3.53 .

The stem borer infestation was noticed in all the surveyed villages during kharif, 2017-18 and 2018-19. In Krishna district the deadhearts percentage range is from 3.48 to 21.46 with the leaf infestation of 8.59 to 24.99 and the tunnel length was observed ranging from 1.5 to $3.05 \mathrm{~cm}$ during kharif, 2018-19. In Krishna district, the maximum leaf infestation was observed in Musunuru mandal in 2017-18 (20.33\%) and 2018-19 (24.99) and 
lowest infestation is recorded in Veerullapadu mandal in 2017-18 (8.59\%) and 2018-19 (11.92). In Guntur district, the maximum leaf infestation was observed in Pedanandipadu mandal in 2017-18 (22.68\%) and 2018-19 (24.11) and lowest infestation is recorded in Narsaraopet mandal and in 2017-18 (9.84\%) and 2018-19 (14.91). However, overall mean infestation was high in Guntur district in kharif 2017-18 (16.68\%), 2018-19 (21.56\%) than in Krishna district in kharif 2017-18 (13.03\%) and 2018-19 (17.76\%). The per cent dead hearts, stem tunneling, no of larve, no of pupae and exit holes were also followed the same trend (Table 2). During the survey some other minor insect pests like Aphids, grasshoppers, green plant bugs, ash weevils etc were also observed.

Table.1 Survey on C. partellus infestation during Kharif 2017-18 and 2018-19 in Krishna and Guntur districts of Andhra Pradesh

\begin{tabular}{|c|c|c|c|c|c|c|c|}
\hline \multirow[t]{3}{*}{ S. No. } & \multirow[t]{3}{*}{$\begin{array}{l}\text { Name of the } \\
\text { Mandal }\end{array}$} & \multicolumn{6}{|c|}{$\begin{array}{l}\text { C. partellus infestation } \\
\text { (Mean data of } 4 \text { fields in four villages and } 40 \text { samples in a field) }\end{array}$} \\
\hline & & \multicolumn{2}{|c|}{ Leaf infestation (\%) } & \multicolumn{2}{|c|}{ Deadhearts (\%) } & \multicolumn{2}{|c|}{ Tunnel length (cm) } \\
\hline & & 2017-18 & 2018-19 & 2017-18 & 2018-19 & 2017-18 & 2018-19 \\
\hline \multicolumn{8}{|c|}{ Krishna District } \\
\hline 1. & G konduru & 9.13 & 15.01 & 4.75 & 14.04 & 1.85 & 2.21 \\
\hline 2 & Mylavaram & 14.10 & 19.12 & 12.25 & 17.12 & 1.82 & 2.68 \\
\hline 3 & Musunuru & 20.33 & 24.99 & 18.86 & 21.46 & 2.96 & 3.05 \\
\hline \multirow[t]{2}{*}{4} & Veerullapadu & 8.59 & 11.92 & 3.48 & 9.86 & 1.50 & 2.25 \\
\hline & Mean & 13.03 & 17.76 & 9.83 & 15.62 & 2.03 & 2.54 \\
\hline \multicolumn{8}{|c|}{ Guntur District } \\
\hline 1. & Narsaraopet & 9.84 & 14.91 & 4.16 & 13.12 & 1.62 & 2.05 \\
\hline 2. & Pedanandipadu & 22.68 & 24.11 & 22.50 & 20.62 & 3.53 & 3.13 \\
\hline 3. & Ponnuru & 17.61 & 22.04 & 21.87 & 19.37 & 2.97 & 4.23 \\
\hline \multirow[t]{2}{*}{4.} & Bhattiprolu & 16.61 & 21.56 & 15 & 20 & 1.93 & 2.80 \\
\hline & Mean & 16.68 & 21.56 & 15.88 & 18.27 & 2.51 & 3.05 \\
\hline
\end{tabular}


Table.2 C. partellus infestation during Kharif 2017-18 and 2018-19 in Krishna and Guntur districts

\begin{tabular}{|c|c|c|c|c|c|c|c|}
\hline \multirow[t]{3}{*}{ S. No. } & \multirow{3}{*}{$\begin{array}{l}\text { Name of the } \\
\text { Mandal }\end{array}$} & \multicolumn{6}{|c|}{ (Mean data of 4 villages and 40 samples in a field) } \\
\hline & & \multicolumn{2}{|c|}{ No of larvae } & \multicolumn{2}{|c|}{ No of pupae } & \multicolumn{2}{|c|}{ Exit hole } \\
\hline & & 2017-18 & 2018-19 & 2017-18 & 2018-19 & 2017-18 & 2018-19 \\
\hline \multicolumn{8}{|c|}{ Krishna District } \\
\hline 1. & G konduru & 0.19 & 0.36 & 0.10 & 0.16 & 0.20 & 0.32 \\
\hline 2 & Mylavaram & 0.26 & 0.40 & 0.14 & 0.22 & 0.28 & 0.46 \\
\hline 3 & Musunuru & 0.36 & 0.49 & 0.17 & 0.28 & 0.47 & 0.49 \\
\hline 4 & Veerullapadu & 0.17 & 0.32 & 0.9 & 0.12 & 0.18 & 0.28 \\
\hline \multicolumn{8}{|c|}{ Guntur District } \\
\hline 1. & Narsaraopet & 0.23 & 0.41 & 0.14 & 0.21 & 0.26 & 0.41 \\
\hline 2. & Pedanandipadu & 0.46 & 0.53 & 0.25 & 0.34 & 0.59 & 0.58 \\
\hline 3. & Ponnuru & 0.37 & 0.47 & 0.16 & 0.23 & 0.55 & 0.43 \\
\hline 4. & Bhattiprolu & 0.31 & 0.50 & 0.17 & 0.30 & 0.39 & 0.54 \\
\hline
\end{tabular}

Table.3 Mandal wise survey on natural enemies fauna during kharif 2017-18 and 2018-19 in Krishna and Guntur districts

\begin{tabular}{|c|l|c|c|c|c|}
\hline \multirow{2}{*}{ S. No. } & Name of the Mandal & \multicolumn{2}{|c|}{ Spiders } & \multicolumn{2}{c|}{ Coccinellids } \\
\cline { 2 - 6 } & & $\mathbf{2 0 1 7 - 1 8}$ & $\mathbf{2 0 1 8 - 1 9}$ & $\mathbf{2 0 1 7 - 1 8}$ & $\mathbf{2 0 1 8 - 1 9}$ \\
\hline Krishna District & 1.2 & 2.6 & 3.5 & 6.4 \\
\hline $\mathbf{1}$ & G konduru & 2.2 & 2.8 & 5.8 & 6.8 \\
\hline $\mathbf{2}$ & Mylavaram & 3.4 & 3.66 & 7.2 & 7.46 \\
\hline $\mathbf{3}$ & Musunnuru & 1.16 & 1.65 & 3.24 & 4.12 \\
\hline $\mathbf{4}$ & Veerullapadu & \multicolumn{4}{|l}{} \\
\hline Guntur| & District & 1.12 & 2.05 & 3.20 & 4.44 \\
\hline $\mathbf{1}$ & Narsaraopet & 2.8 & 3.12 & 6.62 & 7.56 \\
\hline $\mathbf{2}$ & Pedanandipadu & 2.23 & 2.89 & 4.82 & 5.86 \\
\hline $\mathbf{3}$ & Ponnuru & 2.46 & 3.12 & 4.75 & 5.12 \\
\hline $\mathbf{4}$ & Bhattiprolu & & & & \\
\hline
\end{tabular}

Natural enemies like spiders and coccinellids were also recorded during survey and their results showed that in Krishna district spiders and coccinellids fauna are more in Musunuru mandal in kharif $2017-18(3.4 ; 7.2)$ and 2018 19 (3.66; 7.46). In Guntur district, they are more in Pedanandipadu mandal in kharif 2017-18 (2.8; 6.62) and 2018-19 (3.12; 7.56). From the two consecutive years of study, results showed that $C$. partellus infestation and natural enemies are higher in Guntur than in Krishna district. The present results are in agreement with Albert et al., (2006) who reported stem borer damage incidence ranging from 10-15 per cent and also recorded some other pests like, grasshopper, red legged grasshopper, black beetles and two spotted spider mite.

The results were also in conformity with Jyothi, (2016) who recorded high per cent of dead hearts in Guntur district i.e., in Ponnuru 
(21.9\%), Bhattiprolu (20.9) and also recorded more spiders and coccinellids in the Guntur district.

\section{References}

Albert, T., Zhu, X., Reid, $\mathrm{M}$ and Woldemariam, T. 2006. Survey of seed and commercial corn diseases and pests in Ontario and Quebec. Crop Advances: Field Crop Reports.

Jyothi, P. 2016. Screening of maize genotypes against maize stem borers and their management with newer insecticides.
Ph.D Thesis. Acharya N. G. Ranga Agricultural University, Guntur.

Singh, B.U., Sharma, H.C and Rao, K.V. 2011. Mechanisms and genetic diversity for host plant resistance to spotted stem borer, Chilo partellus in sorghum. Journal of Applied Entomology. 135: 333-392.

Singh, J. and Sajjan, S. S. 1982. Losses in maize yield due to different grades (1-9 scale) caused by maize stem borer. Indian Journal of Entomology 44(1): 41-48.

\section{How to cite this article:}

Anil Kumar, K., T. Madhumathi, D.V. Sai Ram Kumar, N. Raj Kumar and Nafeez Umar, Sk. 2019. Survey on the Incidence of Chilo partellus (Swinhoe) in Krishna and Guntur Districts of Andhra Pradesh, India. Int.J.Curr.Microbiol.App.Sci. 8(06): 3131-3135. doi: https://doi.org/10.20546/ijcmas.2019.806.373 